\title{
Культурный ландшафт в системе ценностей восточных славян Приморья (на материале прозаических жанров фольклора XX в.)
}

В настоящее время культурный ландшафрт становится объектом исследования многих гуманитарных, естественных и общественных наук, каждая из которых вкладывает в это понятие свои смыслы, применяет свою методологию, исследуя его на собственном материале. В.В. Дементьева связывает актуализацию этого феномена "с переосмыслением соотношений рукотворного и природного пространств, их взаимодействия" [6, с. 433].

И.Р. Николаев, обращаясь к проблеме прибрежного культурного ландшафта, заявляет о многозначности понятия культурный ландшафт и называет четыре основных существующих в настоящее время подхода к его изучению: "<..> классический ландшафтный географический подход; этнолого-географический или этнокультурный подход; информационно-аксиологический подход; френоменологический подход" [15, с. 243].

В.В Дементьева отмечает: "Наряду с природоцентричным (геоградическим) направлением развивается и культурологическое или культуроцентричное, которое рассматривает, прежде всего, духовную составляющую культурного ландшафрта" [6, с. 435]. Исследовательница разграничивает среду и культурный ландшафрт, считая первую основанием для второго: "<...> главными составными элементами которого [ландшафрта] выступают дороги, архитектурные сооружения <...>" [6, с. 436]. А.С. Кусков и Е.И. Арсеньева культурный ландшафрт определяют как "гармоничное сочетание природной и историко-культурной составляющих" [12, с. 330].

Данная статья посвящена исследованию культурного ландшафта, запечатленного в прозаическом фольклоре Приморья. Фольклористы уже обращались к осмыслению культурного ландшафта. Так, А.А. Иванова, опираясь на фонд географических песен, применяет к фольклорному материалу следующее определение культурного ландшафта: "Под культурным ландшафртом разумеется территориальный природно-культурный комплекс, созданный и/или освоенный сообществом людей" [8] и вычленяет его структуру: "<..> природный ландшафт (или природная среда); сообщество людей, взятое в этнологическом, социальном, семейном, конфессиональном и прочих аспектах; хозяйственная деятельность; селенческо-расселенческая система (или селитьба) как способ пространственной организации/самоорганизации сообщества в природном ландшафрт; языковая система; духовная культура (сфера верований, ритуальной практики, фольклора и других видов народного искусства)" [8]. Особую роль в описании культурного ландшафта исследовательница отводит географической песне, поскольку в ней "исполнитель по сути дела выступает в роли "исследователя" КЛ [культурного ландшафта]" [8].

А.Ф. Григорьев изучал культурный ландшафт на материале фольклора гребенских казаков [4; 5]. "<...> культурный ландшафрт гребенцов, включающий различные объекты окружающей природной среды, <..> образует природно-ландшафртный социокультурный комплекс гармоничной нерасчлененной взаимосвязи природы с человеком, свойственной ещё архаикоязыческой мифологизации, который <...> явился стержневой доминантовой основой в формировании этнической картины мира гребенских казаков" [5, с. 127]. А образ Кавказских гор, по мнению исследователя, маркирует "архаико-языческий мифологизированный образ этносознания казаков, унаследованного ещё

(C) Краюшкина Т. В., 2021

КРАЮШКИНА Татьяна Владимировна, д-р филол. наук, главный научный сотрудник Центра истории культуры и межкультурных коммуникаций Института истории, археологии и этнографии народов Дальнего Востока ДВО РАН (2. Владивосток). E-mail: kvtbp@mail.ru 
от первобытного средневекового мировосприятия со свойственным ему антропоморфизмом" [4, с. 46]. В.А. Лобач, исследуя ландшафртный код топонимических преданий о богатырях, заявляет о его стереотипности $[14$, c. 352].

В.В. Виноградов обращал свое внимание на роль почитаемого места в традиционной культуре: "В нем отражен процесс активного взаимодействия человеческого коллектива и окружающего мира, а также расширения пределов "своей" ойкумены и ее осмысления. Возникший таким образом и поддерживаемый поколениями, существует культурный ландшафт" [2, с. 22].

H.M. Ведерникова и М.Н. Мелютина, исследуя сакральную топографию Кенозерья на материале преданий, легенд и поверий, приходят к заключению: "<...> фольклорные материалы показывают, что святые рощи, церкви, часовни, кладбища, кресты, будучи значимыми визуальными приметами культурного ландшафта Кенозера, являются и содержательными доминантами, выявляя определённые закономерности в духовной организации пространства" [1, с. 102].

Тема дальневосточного пространства рассматривалась в работах литературоведов Дальнего Востока. Так, А.А. Забияко отмечает его роль в формировании фронтирной мифологии: "Суровые условия выживания предопределили сакрализацию пространственных таежных координат <...>" [7, с. 155]. Е.О. Кириллова приходит к выводам, что "образ тайги в творчестве Байкова проявляется как нечто целостное, так и в различных конкретных образах, среди которых центральное место занимают две значительные группы: зооморфные <...> и фритоморфные <...>" [9, с. 97]. Отметим, что прозаический фольклор восточных славян Дальнего Востока и, в частности, Приморья, записанный в XX в., еще не становился материалом для исследования культурного ландшарта, хотя и привлекался при изучении смежных тем, например, языческих представлений о земле в фольклоре [10; 11].

В качестве материала для исследования данной работы послужили тексты сказок (34), легенд (11), поверий (9), преданий (14), быличек (5), устных рассказов (2), произведений народного юмора (9), записанные на территории Приморского края в XX в. Всего было проанализировано 84 текста.

В данном материале было выявлено три жанра сказочного фольклора: сказки о животных, волшебные и бытовые. Поскольку сказки о животных не только знакомили детей с дикими и домашними животными, их повадками, показывали типологию людских характеров, но и транслировали информацию о традиционном русском ландшафрте, на первый взгляд, обезличенном. Да, в сказках о животных не упоминаются наименования земель или населённых пунктов, нет в них личных имён рек или возвышенностей. Но на самом деле этот обезличенный ландшафт легко налагался на ландшафрт местности, где рассказывались сказки, и воспринимался слушателями как знакомый, родной. Упоминаются те реалии, которые необходимы для развития сюжета. Так, в сказке "Лиса и волк" этот набор минимален: речка и два берега реки. На противоположном берегу находится волк, лиса показывает ему, как можно избавиться от блох, а затем возвращается на свой берег. Волк повторяет за лисой, но торопится, в результате не только не освобождается от собственных блох, но собирает и тех, что были на лисе $[18$, с. 44-45]. Значимо в этой сказке восприятие пространства: слушатель сказки видит ситуацию с позиции находчивой лисы, наблюдает за происходящим с её берега, а волк - осмеянный - находится на другом берегу. Так реалии ландшафрта ненавязчиво помогают сдормировать у детей отношение к происходящему.

Кроме ландшафтных природных реалий, в сказках о животных стабильно упоминаются избушки и хаты, в которых живут люди или лесные звери. Пространство делится на два локуса: лес, где обитают звери, и деревню, где находятся люди, при этом все перемещаются из одного локуса в другой и обратно. Звери пользуются дорогой лишь в том случае, когда хотят вступить в контакт с человеком: "<...> лиса пошла, легла на дороге и притаилась, как cnum" [17, с. 20]. На дороге её и подбирает мужик, возвращающийся с рыбалки.

Иное осмысление ландшафрта представлено в волшебных сказках. В них не только очевидно деление пространства на свой мир и мир иной, который может располагаться как под землей, так и на горе или под водой, но в них реализуется география нашего мира, поделённого на город и деревню 
(в единственном числе). Особенностью волшебных сказок является не только реализация объектов культурного ландшафрта по их прямому назначению: по дорогам персонажи ходят или ездят на конях, у развилок задумываются о выборе маршрута, ныряют в озёра, переходят по мосту над рекой, залезают на высокую гору или спускаются в глубокую яму, живут в избах или в теремах, набирают воду в колодце.

Кроме обычных ландшафтных реалий, в этом жанре встречаются и особенные. Так, они сами, изменяя природу, могут становиться персонажами (например, печка или яблонька в сказке "Гуси-лебеди"). В предметы культурного ландшафта могут превращаться герой и его невеста, прячась от преследователей. "А девушка как засльшала погоню, оборотила Ваню в попа, а себя в иерковь" [17, с. 47]. И преследователи не в состоянии отличить оборотней от настоящий ландшафтных реалий, кроме того, оборотни обладают теми же свойствами, что и настоящие реалии. Преследователи "подлетели, а в иеркви зазвонил колокол, вышел на алвон поп с кадилол и завел свое <...>. Окурил их ладанол" [17, с. 47].

Бытовые сказки вводят действие сюжета в городское или деревенское пространство, изображают крестьянскую избу или дом барина. В сказке "Три загадки" говорится об уничтожении дома как мести за грубое обращение. Так, солдат просится ночевать, хозяин дома разрешает, но сначала солдат должен угадать названия предметов, а иначе его ждут оплеухи. Солдат не может угадать, что кошка - это чистота, лампа - светлота, а дождь - благодать. Утром солдат обливает кошку керосином и поджигает, уходя, загадывает хозяину свою загадку: "Ваша чистота схватила светлоту, понесла на высоту, как не даст Бог благодать, так тебе дола не видать" [16, с. 170].

Былички - жанр, повествующих о представителях низшей славянской мифологии: домовых, леших, русалках, овинниках и пр., транслирует присущую ему систему культурного ландшафрта. В этом жанре чётко выражено деление мира на освоенное (т.е. принадлежащее человеку) и неосвоенное пространство (там, где живут персонажи нечеловеческой природы). Однако традиционное сознание наделяет неосвоенное пространство привычными реалиями: например, избушку, где живёт нечисть. Старушка, которую пригласили вечером на родины и с небывалой скоростью довезли к роженице, понимает, где она оказалась: "Тут бабушка наша всполнила про жабу [которую днёл подсаживала на кочку] и догадалась, что она на родинах у чёрта, потолу что только в болоте водятся черти" [17, с. 69].

В неосвоенном пространстве запрещены действия, обязательные в пространстве освоенном, так как это приведет к изменению пространства. Принимая роды, бабушка не молится, "потолу что если бы стала творить молитвы, то всё исчезло бы, она очутилась бы в болоте" [17, с. 69]. Другим таким действием становится крик петуха: он оказывается сильнее наваждения: "Все пропало, а старушка сидит на краю болота на кочке" [17, с. 69]. Так традиционное сознание транслирует идею сосуществования разных миров в одной точке пересечения координат и различной реализации их ландшафтов, причём одновременно героиня можно находиться только или в одном ландшафрте, или в другом.

Но возможно и создание безопасного локуса в пространстве неосвоенном. Такой способностью обладает человек, наделенный особыми знаниями, внешне ничем не примечательный. Для придания эфрфекта достоверности действие привязывается к реально существовавшим в недавнем прошлом географрическим единицам: "Ходили мы ходокали в ДВК [Дальневосточный край, был образован в 1926 г., реорганизован в 1938 г.] втроёл. Пришли в Ольгинский район. <...>. Вот в одной деревне, забыл уж название, зашли к старику-хохлу Полтавской губернии, остались отдьхать у него на три дня" [17, с. 69-70]. Старик зовет с собой рассказчика на охоту, но велит не двигаться с места. И создаёт для героя особое пространство: "Поставил меня среди дороги, очертил вокруг меня большой круг и стал свистеть. Глянул я - и сердие у меня замерло, оболлел весь: ползут змеи видимо-невидимо, бегут крысы, бурундуки, зайцьı" [17, с. 70]. Однако, никто из животных не в состоянии оказывается перейти начертанный круг.

Но представители нечистой силы могут не только входить в освоенное пространство, но и изменять его. Как, например, ткач, который потребовал у 
мужика большой объем работы. Мужик, не веря, в шутку ответил, что если ткач все переделает, то может хату раскрыть. Так и происходит: ткач сначала раскрывает за день хату, а затем за ночь покрывает её вновь, тем самым демонстрируя свою принадлежность к нечисти.

Текст, относящийся к религиозно-назидательным легендам, был опубликован А.П. Георгиевским в 1929 г. Легенда относится к т.н. снам Богородицы, где Она видит предстоящую гибель своего Сына. Легенда начинается с описания места: "На һори на осияньскии, на зэлли на хрэстиянскии, тал Пречиста Мати спала и зночьвала" [3, с. 100]. Отнесённость земли к христианской территории как маркёр народной географиии - показатель вещего сна. Но в самом сне присутствует уже другое разделение мироздания - на двухчастную модель: небо, откуда спускаются ангелы, и земля, где распинают Христа, причём крови Христа не дают пасть на землю: "Анһэльь свять з нэбэс злиталь, золотьи чашь пидставляль, ёһо святои крови до зэлли нэ допуськаль" [3, с. 100]. Пречистая кровь оберегается от земли: так пресекается смешение миров. И крест, на котором распят Христос, будто выносится за рамки мироздания, поскольку не указано его местонахождение.

Ещё одна славянская легенда (космогоническая), бытовавшая в среде переселенцев, связана с описанием Дальнего Востока - изобилующей богатствами земли. Она возникла на основе рассказов тех, кто лично побывал на Дальнем Востоке, и вошла в фольклорный фонд ещё на родине переселенцев. Переселенцам рассказывали о необычайной близости земли и неба: "<...> тал край света. Бабы валькали бельё бьют и на небо вальки кладут, потому что тал зелля с небол сходятся. Небо совсел низенько" [18, с. 26]. Земля maлn противопоставлялась земле здесь (т.е. родине переселенцев), причём не в пользу последней: "Лесу тал на Дальнел Востоке - хоть удавись, воды хоть утопись, зелли - хоть подавись, а есть не проси. Места ешё совсел не обжитые, не заселённые. Где колу понравилось, тал и паши, сей, лесу не покупай, руби, строй дола, какие тебе хочется" [18, с. 26].

Если рассмотренные выше легенды бытовали в других регионах России, то этиологические легенды, описывающие появление женьшеня, видимо, проникли в фрольклорный фонд переселенцев из устного народного творчества коренных народов или китайцев. И реалии культурного ландшафрта этих текстов уже соотносятся с территорией Дальнего Востока. Если один текст относит появление женьшеня к доисторическим временам, "когда и живого-то ешё ничего не было, одна вода да зелля" [17, с. 60], а после того, как женьшень порождает подобных себе, он прячется в месте, "где поглуше да поспокойней, почему и найти его трудно" [17, с. 60]. Две другие легенды уже связывают появление женышеня с человеком, поэтому и описываются в текстах реалии, созданные человеком. В первой легенде это ловушка, устроенная завистником - глубокая яма, полная острых камней и прикрытая веточками [17, c. 61], а в сюжете второй противопоставляются горы как маркёр вольной жизни и дом богача, где герой влюбляется в дочь вылеченного им богача. Но богач отказывает нищему жениху, и тот снова уходит в горы. Вскоре вслед за ним отправляется и девушка. Именно в горах влюблённая, преследуемая погоней, меняет свое обличье: "Видит она, что не уйтu, и превратилась в птииу. $A$ юноша стал женьшенел. C тех пор они всегда влесте, где птичка, эта есть, тали и женьшень ищи" [17, с. 62].

Другие легенды, связанные с плантациями женьшеня, рассказывают о случайном обнаружении и сокрытии этого богатства от чужого глаза, причём для достоверности событий в текстах употребляются имена В.К. Арсеньева, созданного им литературного героя Дерсу, Татьмянина (кто это - выяснить пока не удалось). В текстах описывается и удивительная способность корня перемещаться в пространстве. Так, корень, на который человек повесил трубку, вдруг исчезает и оказывается в другом месте: "Потол уже другой человек по друголу ручью корень нашёл и трубку на нёл. Принёс домой, а сосед признал. То-то удивились!" [17, с. 64].

С обозначенными выше легендами о женьшене соотносятся поверья. В этих небольших текстах встречается характерная деталь: в центре ландшафта находится корень жизни, а все прочие реалии ландшафта связаны с ним. Именно женьшень - главный маркёр особого приморского ландшафта, но упоминается и другой - тайга. Впрочем, наименование тайга иногда 
обобщается до общеупотребительного наименования лес. В этом жанре обозначен значимый компонент традиционного сознания - ориентация в сложном пространстве, чего не было выявлено в других жанрах: "Главное - тайгу понилать надо, чтобь, значит, не закружить. Вдарился, скажел, в такол направлении, ну и держи" [17, с. 65]. Обращается внимание на соотношение затраченных усилий и достижения поставленной цели: "Вообще-то, конечно, корень надо знать, чтоб не бить ноги попусту" [17, с. 65].

Тексты поверий сосредоточены на описании места произрастания женьшеня. Оно точно не описано, делается акцент на его тайности, удалённости и закрытости от постороннего глаза. Существуют особые приметы, связанные с ландшафтом, указывающие на место, где растёт корень. В этих приметах очевидна модель подобия, присущая традиционному сознанию: "B лес заходишь когда - иди тихо. На лещину гляди. Увидищь ветку скрученную, на корень похожую - значит, он близко" [17, с. 65]. Корень при этом одушевляется: этой ландшафтной реалии приписывается способность прятаться, ускользать из рук корнёвщика. Считается, что корень имеет свою звезду, с которой он связан: если падает звезда, то и корень лишается жизни. Но при этом на месте падения звезды, как гласит другое предание, рождается корень.

Предания, чьи сюжеты возникли на основе реальных событий, происходивших в годы Гражданской войны на Дальнем Востоке, транслируют реальный ландшафт Приморья. Причём если предания рассказывают участники события или знавшие их люди, то ландшафт в текстах сохраняет реалистические черты, подробное описание: "Жили мы на пасеке в сопках. Стояла тали хата старая и олшаник. Сразу за хатой была пасека, а дальше - заилка" $[18$, c. 77]. В эту хату нагрянул бандит и потребовал у молодой хозяйки отдать ему деньги. Не испугавшись, она указал ему на сундук. Когда он залез туда в поисках денег, женщина переломила ему шею крышкой. Показателем достоверности описываемого события выступает и место его захоронения: "Закопали его в кустах подальше, да вот и всё!" [18, с. 78].

Наименование села также служит признаком достоверности событий. Так, в одном из преданий повествует о женитьбе солдата, привезшего к себе на родину жену из Литвы. В этом тексте сталкиваются два географически неравнозначных объекта, неравнозначность которых не воспринимается традиционным сознанием, - село и земля: Лобановка и Литва. "В селе Лобановке жил бедный парень Мельников Григорий. Взяли его в арлию, и воевал он в герланскую войну в Литве" [18, с. 78]. Так в предании отражается народное наименование земли - Литва, а не официальное название Виленской и Курляндской губернии, на чьих территориях располагалась в годы Первой Мировой войны Литва. Таким образом в тексте одновременно используются официальное название своего пространства - населенного пункта Лобановка - и пространства чужого, наименованного народным названием - Литва.

Своеобразным маркёром ландшафта Приморья, обезличенного, стандартного, надо сказать (одно село), может выступать реальное историческое лицо и различные социальные группы, имеющие отношение к периоду Гражданской войны: "Не полню, рассказывали, белье или япониы были. А Лазо - в деревне" [18, с. 77]; "Было это в 1924 г., когда по сопкал пробирались то хунхузы, то ширяевиь" [18, с. 77].

Видимо, привезённые с родины фольклорные тексты, сохраняют ландшафртную схему, присущую фрольклорному фонду места выхода переселенцев, новыми - приморскими - ландшафтными реалиями старые предания не наполняются. Отсутствие конкретики - одна из особенностей фольклорного ландшафта преданий: одно село, в город на базар ехать [17, с. 67]. Значимой чертой ландшафрта, отражённого в предании, является указание реалий, только значимых - для характеристики персонажей или развития сюжетной линии. Вот как описывается маршрут в логово разбойника: "Bom nо лесныли дорогал да тропал добрались до разбойничьего гнезда <...>" [17, с. 67]. В другом предании, об обманутом старике, которому солдат в обмен за хлеб и баклажку мёда на воротах целую рещептюгу написал, также противопоставляется малая родина героя и другой населенный пункт, причём малая родина сопровождается, как в рассмотренном выше предании, числительным. Так малая родина конкретизируется расплывчато, а город, видимо, в подобной конкретизации в традиционном мышлении не нуждается: "Жили да были в 
одной деревеньке старик со старухой" [18, с. 80]; "Приехал в город <...>" [18, c. 80].

Уникален текст, напечатанный в сборнике "Фольклор Дальнеречья". Это самозапись Л.Н. Ляхова, но год фриксации в издании не указан. Учитель по профессии, Л.Н. Ляхов собрал в единый текст, по форме своей напоминающий сочинение, микротексты-предания, связанные с уголками села Новотроицкого. Эти микропредания свидетельствуют об особенности менталитета восточных славян - давать наименование каждому уголку земли. Наименование пространства в традиционной культуре существует не только для того, чтобы отличать его от других, но это и один из способов освоения ландшафрта, преобразования неосвоенного пространства в пространство освоенное. Л.Н. Ляхов отмечает: "Метко и поэтично отразились в названиях природные особенности этих участков и запечатлелась местная история. Эти названия крепко держатся в народнол обиходе и по сей день" [18, с. 76].

В ландшафтную среду оказываются вписаны имена людей через сферу их профессиональной деятельности ("У Лаврина на заилке был дегтярный завод. "Завод" представлял собой маленькую сараюшку <...>. Давно уже нет ни Лаврина, ни его сельи, а название "Лавринов ключ" прочно вошло в геограббю нашего села" [18, с. 74-75] ), обыденного труда ("<...> потол Верино озеро. Жену Колесникова Сергея звали Верой. Они тал жили. Вера в этол озере белье стирала, била праникол" [18, с. 74]) или внешнего вида ("Стеклянникова [падь] называется так потолу, что тали была заимка какого-то мужика, который носил очки" [18, с. 74]). Так происходит переплетение истории и географии населенного пункта и его окрестностей. Так складывается история малой родины - через обыкновенных, ничем не выдающихся людей, сначала деятельностью своей, а затем и именами освоившими пространство новой родины. Но в тексте Л.Н. Ляхова доминируют наименования без указания истории возникновения. Скорее всего, это вызвано уже утратой памяти. Активное бытование названий связано с активным их употреблением в профессиональной сфере: "Наиболее полно сохранились названия по реке, потолу что тал работают сплавщики и постоянно эти названия употребляют для ориентирования" [18, с. 74].

Но при этом сохраняются в воспоминаниях названия улиц, уже переименованных: "Полню названия улии села, бытовавшие в 30-е годы: "Каиап$к a^{\prime \prime}$ - тали жили тогда переселенцы из Белоруссии, "Вольнка" - от переселениев из Вольнской губернии (сейчас улииа Пионерская), "Подсопка" - жили под сопкой, "Япония" - как бь отделялась от села-латерика (сейчас улица Ковальчука)" [18, с. 73].

Л.Н Ляхов отмечает ещё одну уникальную деталь культурного ландшафта восточных славян Приморья: наличие кроме официальных названий и названий мене официальных (градация именно такая, менее четкая, чем официальное / неофициальное), одновременное бытование тех и других и разграничение первых от вторых. Повествуя о Верином озере, он пишет: "Так и назвали озеро Веринылм. Впрочел, более офбицильно - Колесниково озеро" [18, c. 74].

Обращает на себя внимание реализация присущей традиционной культуре пространственной парадигмы, где чётко деление на своё и другое. О.А. Лавренова отмечает: "Универсальные категории, которые находят своё материализованное выражение в пространстве, фрормируют тем самым культурный ландшафрт. Например, столь значимая для любой культуры категория "Другого" имеет своё выражение не только в метафрорическом и внутриличностном пространстве, но и в ландшафте - в заборах, изгородях, в административных и естественных границах, разделяющих локальные культуры" $[13$, c. 52].

Ценность этого текста состоит ещё и в том, что в нем представлена модель разграничения своих наименований пространства и наименований пространства, используемых другими (в данном случае - жителями другого населённого пункта): свои употребляются в обиходе, а другие наименования известны, но активно не употребляются. Другие начинают использоваться тогда, когда нет своих или когда они по какой-либо иной причине становятся актуальны: "Здесь справа будет Зухов залив, потол Котова протока, слева 
- Бугаев залив <...>, Новотроиикое озеро (это озеро зовут так междуреченuьь), слева-каленное озеро" [18, с. 75].

В анализируемом тексте присутствует деление ландшафта, связанное с принадлежностью людей одной национальности или близкородственных этносов к населенным пунктам: т.е. окрестностям своего села и другого села, причём незнание названий, используемых жителями другого села, возможно, позиционируется как отсутствие названия: "Проезжсаел мило бывшего селения Третья падь. Тал много озер: Большое, Узкое, Плисенково, Кочковатое, Моховое и другие - без названия" [18, с. 75].

Выводя повествование за территорию села Новотроицкого, респондент демонстрирует четкое понимание деления пространства на своё и другое, называя только село, а реалии ландшафта лишь перечисляет, не называя их. Возможно, так реализуется ещё раз, пусть и неосознанно, разграничение своего и другого пространства, причём своего - много, поскольку оно названо, а другого - немного, неназванного: "Зател справа будет Левкин залив, Огородная протока, слева - Четвертая падь. Справа ещё много заливов и озёр, но это все уже бывшая Семеновка" [18, с. 76]. Очевидно, что другое пространство в фольклорном тексте описывается как сжатое, сконцентрированное, в то время как свое наделяется противоположными качествами.

В сборнике "Фольклор Дальнеречья" отмечены два текста, отнесённых к жанру устного рассказа. Зафиксированные в 1960 г. в с. Новотроицком и Лобановке от участников Гражданской войны на Дальнем Востоке, сюжеты устных рассказов относят к событиям из жизни рассказчиков тому периоду, когда они принимали участие в Гражданской войне. В данном жанре упоминаются как реально существующие населенные пункты (г. Дальнереченск, с. Веденка), так и тип населенного пункта, без указания названия: "Bom paз мы отступали через село Веденку" $[18$, с. 76]; "В деревню сходим - чтоб не материться, ничего" [18, с. 76]. Указание на конкретный населённый пункт связано с единичным событием, а без указания названия - с повторяющимся однотипными событиями. При этом упоминание таких ландшафтных реалий, как болото, речушка и пр., служат маркёрами достоверности событий: "Белье - через болото, что за мельницей. Болото-то глубокое, тали и речушка" [18, c. 76].

Произведения народного юмора, а это преимущественно анекдоты, использует те реалии культурного ландшафта, которые необходимы для реализации сюжета. За рамками повествования, как правило, оказывается упоминание населенного пункта, где происходит событие, не упоминается и жилище. Если же о населенном пункте говорится, то внимание сосредоточено на том его локусе, который связан с развитием сюжета: "Поехал однажды лужик в город на базар" [18, с. 86].

Чаще обозначаются значимые реалии, например, калитка, как финишная точка маршрута: "Быєало, народится у какой бабы дитё, вот мужик идет к nопу. Подойдет к калитке и кричит <...>" [18, с. 85]. Или часть ландшафта становится местом встречи персонажей, как, например, кузница: "Расковался у попа конь. Проезжает он мило кузнецьь <...>" $[18$, с. 85]. При этом кузница никак не характеризуется.

В анекдоте "Як мы татарву воевали" говорится о хлопцах, изготовивших деревянную пушку и начинивших ее галушками. Народный юмор приписывает галушке смекалку в победе над киргизякой, причём значимыми для развития сюжета оказываются реалии ландшафота: "А одна галушка улная былла.. Та за киригизякой! Кудыь вин - тылу й вона, куды вин - туды й воныь. Вин тоди вскочил в курень, в вона стала под оконце та й пиджижае. Вин только двери отчинил, а вона баи по лбу!" [18, с. 87].

Таким образом, культурный ландшафрт, реализованный в сказочной и несказочной фольклорной прозе восточных славян, зафиксированной в Приморском крае в XX в., транслирует сложный комплекс представлений о культурном ландшафрте, сочетающий как мифологические воззрения, традиционную систему представлений о пространстве, так и бытовое восприятие ландшафта, характерное для XX в.

M.С. Хроменко, исследовав народные представления о модели мироздания, приходит к выводу: "<...> в традиционных фольклорных текстах, записанных в Приморье с 1967-2008 гг., нашли отражение народные представления 
о дуализме окружающего мира <...>. Однако целостной модели мироздания восстановить не удается, поскольку наблюдается ее разрушение" [19, с. 326]. Наши наблюдения над проанализированным материалом свидетельствуют о том, что целостная модель культурного ландшафта многоуровневая, она складывается из различных компонентов, порой противоположных: изменяемости и неизменяемости реалий ландшафта; зафиксированного нахождения в пространстве или способности реалий культурного ландшафрта перемещаться; культурный ландшафт выстраивается из стереотипных реалий и при этом наполняется новыми, ранее неизвестными; наполняется неконкретными, безымянными, существующими лишь в воображении рассказчика населенными пунктами или же существующими в реальности.

Все реалии культурного ландшафрта оцениваются фольклорным сознанием с позиции своего, другого или чужого. Каждый из исследованных жанров обладает индивидуальным набором представлений о культурном ландшафте и спецификой их реализации. Специфика отражения реалий ландшафта заключается в минимальном описании объекта и упоминании его только тогда, когда он нужен для развития сюжета: т.е. тот или иной объект существует только в том случае, если рядом с ним (или в нём) находится персонаж. Без персонажей ландшафтные реалии в фольклорной прозе не существуют.

Реализованные в фольклорной прозе представления о культурном ландшафте апеллируют к таким духовно-ценностным ориентирам, как патриотизм, семья, труд, природа, сохраняют до наших дней не только базовые представления восточных славян, но и обладают существенным потенциалом для их трансляции современному российскому обществу.

\section{Литература}

1. Ведерникова Н.М., Мелютина М.Н. Духовная культура Кенозерья в сакральной топографии и эпической традиции // Наследие и современность. 2019. Т. 2 . № 2. C. $95-104$.

2. Виноградов В.В. Северорусские почитаемые места в слове и изображении: $\kappa$ проблеме взаимодействия фольклора и художественного творчества // Северорусские почитаемые места: топика святынь. Виноградов В.В. избранные статьи, диссертация. Санкт-Петербург: Автономная некоммерческая организация "Пропповский центр: гуманитарные исследования в области традиционной культуры", 2019. С. 13-322.

3. Георгиевский А.П. Русские на Дальнем Востоке. Фольклорно-диалектологический очерк. Выпуск 4. Фольклор Приморья. Владивосток: Типография ДГУ, 1929. $119 \mathrm{c.}$

4. Григорьев А.Ф. Концепт Кавказских гор в фольклорном сознании гребенских казаков // Kant. 2015. № 1 (14). C. 45-47.

5. Григорьев А.Ф. Культурный ландшафт - стержневая доминанта картины мира гребенских казаков // Теория и практика общественного развития. 2011. № 7. С. $125-127$.

6. Дементьева В.В. Подходы к определению понятия "культурный ландшафт" // Байкальские встречи-VIII: Историко-культурное наследие региона как фактор сощиально-экономического развития. Мат-лы междунар. науч.-практ. конф. / отв. ред. Р.И. Пшеничникова Улан-Удэ: ВСГИК, 2014. С. 433-439.

7. Забияко А.А. Мифология дальневосточного фронтира в сознании писателей-эмигрантов // Религиоведение. 2011. № 2. С. 154-169.

8. Иванова А.А. Исполнитель как "исследователь" культурного ландшафта (по материалам географических песен). URL: http://kizhi.karelia.ru/library/ ryabinin-2007/451.html (Дата обращения: 05.07.2021).

9. Кириллова Е.О. Творчество писателя дальневосточной эмиграции Н.А. Байкова как пример культурного взаимодействия в условиях трансграничья. Региональный образ священного дерева // Вестник Череповецкого государственного университета. 2016. № 4 (73). С. 92-98.

10. Киселева М.С. Языческие и христианские представления о земле в фольклоре и древнерусской литературе: диссертация на соискание ученой степени канд. фрилол. наук по специальности 10.01.09 - фольклористика. Владивосток: ДВФУ, 2012. 217 с.

11. Киселева М.С. Языческие и христианские представления о земле в фольклоре и древнерусской литературе: автореферат диссертации на соискание ученой степени канд. филол. наук по специальности 10.01.09 - фольклористика. Улан-Удэ, 2012. 26 с.

12. Кусков А.С., Арсеньева Е.И. Феномены традиционной живой культуры поморов в пространстве культурных ландшафтов Русского Севера: формы проявления и туристское использование // Стратегия развития индустрии гостеприимства и туризма: 
мат-лы IV Междунар. интернет-конф. Науч. электронное издание локального распространения / под общ. ред. Е.Н. Артёмовой, Ю.С. Степанова. 2011. С. 320-330.

13. Лавренова О.А. "Время больше пространства...": историческое и мифологическое время в культурном ландшафте // Вестник Томского государственного университета. 2010. № 338. С. 52-56.

14. Лобач В.А. Богатыри, осилки и девы-воительницы в топонимических преданиях восточных славян // Балто-славянские исследования-ХХ. Сб. науч. тр. Сер. "Балто-славянские исследования" Москва: Институт славяноведения РАН, 2019. С. 350383.

15. Николаев И.Р. Прибрежный культурный ландшафрт: определение и содержание понятия // Мировые тренды и музейная практика в России: сб. ст. междунар. науч. конф. / отв. ред. А.А. Сундиева. М: РГГУ, 2019. С. 241-249.

16. Русские сказки Сибири и Дальнего Востока: легендарные и бытовые / сост. Н.В. Соболева при уч. Н.А. Каргаполова. Новосибирск: Наука, СО, 1992. 304 с.

17. У ключика у гремучего: Дальневосточный фольклор / сост. Л. Свиридова. Владивосток: Дальневост. кн. изд-во, 1989. 255 с.

18. Фольклор Дальнеречья / сост. Л.М. Свиридова. Владивосток: Изд-во ДВГУ, 1986. 288 c.

19. Хроменко М. С. Народные представления о модели мироздания // Вестник ЧГПУ. 2010. № 4. С. 321-330.

\section{Транслитерация по ГОСТ 7.79-2000 Система Б}

1. Vedernikova N.M., Melyutina M.N. Dukhovnaya kul'tura Kenozer'ya v sakral'noj topografii i ehpicheskoj traditsii // Nasledie i sovremennost'. 2019. T. 2. № 2. S. 95-104.

2. Vinogradov V.V. Severorusskie pochitaemye mesta v slove i izobrazhenii: k probleme vzaimodejstviya fol'klora i khudozhestvennogo tvorchestva // Severorusskie pochitaemye mesta: topika svyatyn'. Vinogradov V.V. izbrannye stat'i, dissertatsiya. Sankt-Peterburg: Avtonomnaya nekommercheskaya organizatsiya "Proppovskij tsentr: gumanitarnye issledovaniya v oblasti traditsionnoj kul'tury", 2019. S. 13-322.

3. Georgievskij A.P. Russkie na Dal'nem Vostoke. Fol'klorno-dialektologicheskij ocherk. Vypusk 4. Fol'klor Primor'ya. Vladivostok: Tipografiya DGU, 1929. 119 s.

4. Grigor'ev A.F. Kontsept Kavkazskikh gor v fol'klornom soznanii grebenskikh kazakov // Kant. 2015. № 1 (14). S. 45-47.

5. Grigor'ev A.F. Kul'turnyj landshaft - sterzhnevaya dominanta kartiny mira grebenskikh kazakov // Teoriya i praktika obshhestvennogo razvitiya. 2011. № 7. S. 125127.

6. Dement'eva V.V. Podkhody k opredeleniyu ponyatiya "kul'turnyj landshaft" // Bajkal'skie vstrechi-VIII: Istoriko-kul'turnoe nasledie regiona kak faktor sotsial'no-ehkonomicheskogo razvitiya. Mat-ly mezhdunar. nauch.-prakt. konf. / otv. red. R.I. Pshenichnikova Ulan-Udeh: VSGIK, 2014. S. 433-439.

7. Zabiyako A.A. Mifologiya dal'nevostochnogo frontira v soznanii pisatelej-ehmigrantov // Religiovedenie. 2011. № 2. S. 154-169.

8. Ivanova A.A. Ispolnitel' kak "issledovatel'" kul'turnogo landshafta (po materialam geograficheskikh pesen). URL: http://kizhi.karelia.ru/library/ryabinin-2007/451.html (Data obrashheniya: 05.07.2021).

9. Kirillova E.O. Tvorchestvo pisatelya dal'nevostochnoj ehmigratsii N.A. Bajkova kak primer kul'turnogo vzaimodejstviya v usloviyakh transgranich'ya. Regional'nyj obraz svyashhennogo dereva // Vestnik CHerepovetskogo gosudarstvennogo universiteta. 2016. № 4 (73). S. 92-98.

10. Kiseleva M.S. YAzycheskie i khristianskie predstavleniya o zemle v fol'klore i drevnerusskoj literature: dissertatsiya na soiskanie uchenoj stepeni kand. filol. nauk po spetsial'nosti 10.01.09 - fol'kloristika. Vladivostok: DVFU, 2012. $217 \mathrm{~s}$.

11. Kiseleva M.S. YAzycheskie i khristianskie predstavleniya o zemle v fol'klore i drevnerusskoj literature: avtoreferat dissertatsii na soiskanie uchenoj stepeni kand. filol. nauk po spetsial'nosti 10.01 .09 - fol'kloristika. Ulan-Udeh, 2012. 26 s.

12. Kuskov A.S., Arsen'eva E.I. Fenomeny traditsionnoj zhivoj kul'tury pomorov v prostranstve kul'turnykh landshaftov Russkogo Severa: formy proyavleniya i turistskoe ispol'zovanie // Strategiya razvitiya industrii gostepriimstva i turizma: mat-ly IV Mezhdunar. internet-konf. Nauch. ehlektronnoe izdanie lokal'nogo rasprostraneniya / pod obshh. red. E.N. Artyomovoj, YU.S. Stepanova. 2011. S. 320-330.

13. Lavrenova O.A. "Vremya bol'she prostranstva...": istoricheskoe i mifologicheskoe vremya v kul'turnom landshafte // Vestnik Tomskogo gosudarstvennogo universiteta. 2010. № 338. S. 52-56.

14. Lobach V.A. Bogatyri, osilki i devy-voitel'nitsy $\mathrm{v}$ toponimicheskikh predaniyakh vostochnykh slavyan // Balto-slavyanskie issledovaniya-XX. Sb. nauch. tr. Ser. "Balto-slavyanskie issledovaniya" Moskva: Institut slavyanovedeniya RAN, 2019. S. 350-383. 
15. Nikolaev I.R. Pribrezhnyj kul'turnyj landshaft: opredelenie i soderzhanie ponyatiya // Mirovye trendy i muzejnaya praktika v Rossii: sb. st. mezhdunar. nauch. konf. / otv. red. A.A. Sundieva. M: RGGU, 2019. S. 241-249.

16. Russkie skazki Sibiri i Dal'nego Vostoka: legendarnye i bytovye / sost. N.V. Soboleva pri uch. N.A. Kargapolova. Novosibirsk: Nauka, SO, 1992. 304 s.

17. U klyuchika u gremuchego: Dal'nevostochnyj fol'klor / sost. L. Sviridova. Vladivostok: Dal'nevost. kn. izd-vo, 1989. 255 s.

18. Fol'klor Dal'nerech'ya / sost. L.M. Sviridova. Vladivostok: Izd-vo DVGU, 1986. $288 \mathrm{~s}$

19. KHromenko M. S. Narodnye predstavleniya o modeli mirozdaniya // Vestnik CHGPU. 2010. № 4. S. 321-330.

Краюшкина Т. В. Культурный ландшафт в системе ценностей восточных славян Приморья (на материале прозаических жанров фольклора XX в.).

В статье на материале сказочной и несказочной прозы восточных славян, зафиксированной в Приморском крае в XX в., исследуется реализация представлений о культурном ландшафте. Делаются выводы о том, что каждый из исследованных жанров обладает индивидуальным набором представлений о культурном ландшафте и спецификой их реализации, при этом в совокупности жанры фольклорной прозы отражают как мифологические воззрения, традиционную систему представлений о пространстве, так и бытовое восприятие ландшафта, при этом сами реалии наделяются порой противоположными признаками. Реализованные в фольклорной прозе представления о культурном ландшафре апеллируют к ряду духовно-ценностных ориентиров восточных славян.

Ключевые слова: культурный ландшафы, сказочная проза, несказочная проза, фбольклор Приморья, систела иенностей традиционной культуры, свой, чужой, другой.

Krayushkina T. V. The cultural landscape in the value system of the Eastern Slavs of Primorye (based on the material of prose genres of folklore of the 20 th century).

The article examines the realization of ideas about the cultural landscape based on the material of the fabulous and non-fabulous prose of the Eastern Slavs, recorded in the Primorsky Territory in the twentieth century. It is concluded that each of the studied genres has an individual set of ideas about the cultural landscape and the specifics of their implementation, while in the aggregate the genres of folklore prose reflect both mythological views, the traditional system of ideas about space, and everyday perception of the landscape, while the realities themselves sometimes endowed with opposite signs. The ideas about the cultural landscape realized in folklore prose appeal to a number of spiritual and value orientations of the Eastern Slavs.

Key words: cultural landscape, fairy-tale prose, non-fairy-tale prose, folklore of Primorye, the system of values of traditional culture, one's own, someone else's, another

Для цитирования: Краюшкина Т. В. Культурный ландшафт в системе ценностей восточных славян Приморья (на материале прозаических жанров фольклора XX в.) // Ойкумена. Регионоведческие исследования. 2021. № 3. С. 38-47. DOI: 10.24866/1998-6785/2021-3/3847

For citation: Krayushkina T. V. The cultural landscape in the value system of the Eastern Slavs of Primorye (based on the material of prose genres of folklore of the 20th century) // Ojkumena. Regional researches. 2021. № 3. P. 38-47. DOI: 10.24866/1998-6785/2021-3/38-47 